\title{
THREE MODES OF TERROR: TRANSCENDENCE, SUBMISSION, INCORPORATION
}

\author{
RICHARD RUSHTON
}

In this article I discuss three modes of terror. The first, derived from George Orwell's Nineteen Eighty-four, sees terror as an operation of the narcissistic fusion of self and other: terror is produced when the ways of the world are reduced entirely to the narcissistic confines of the self.' The second conception of terror, which emerges from Kazuo Ishiguro's The Remains of the Day, understands terror as a mode in which the desires of the self are forgone in deference to the authority to which one submits. ${ }^{2}$ This second mode of terror is thus characterized by a willing submission to the other. A third notion of terror, taken from Lucile Hadzihalilovic's recent film, Innocence (France, 2004), posits terror as something that must be accepted as part and parcel of human existence. From this perspective, terror is not something which the human being should strive to transcend (as occurs in Nineteen Eighty-four) or to which one must submit (as is the case with The Remains of the Day). Rather, for Innocence, terror is something which must be incorporated.

These claims are made from within the context of psychoanalysis, most specifically by way of an understanding of Jean Laplanche's challenge to psychoanalysis: that the unconscious constitutes an 'internal étrangèreté' (alienness) which is both put in place and maintained by an 'external étrangèreté'. ${ }^{3}$ For Laplanche, the origins of the unconscious are external. The unconscious does not spontaneously or biologically arise from within the human subject, but is instead an internalized externality, an external alien inside me. ${ }^{4}$ Orwell's and Ishiguro's novels narrate ways of quashing or expelling the external, alien qualities of the unconscious, whereas Hadzihalilovic's extraordinary film offers a version of the implantation of the internal étrangèreté which is fundamental to the formation of

1. George Orwell, Nineteen Eighty-four (Harmondsworth: Penguin, 1989 [1949]).

2. Kazuo Ishiguro, The Remains of the Day (London: Faber, 1989).

3. Étrangèreté, 'strangerness' or 'alien-ness' is Laplanche's neologism which attempts to capture the specific otherness of the unconscious, insofar as he conceives of the unconscious as an internalized otherness that is implanted externally by the child's interactions with other people. On this point, and on the translation into English of étrangèreté, see John Fletcher's note in Laplanche, Essays on Others, ed. by John Fletcher (London and New York: Routledge, 1998), p. 62, n. 21.

4. Jean Laplanche, 'La Révolution copernicienne inachevée, in La Révolution copernicienne inachevée: Travaux 1965-1992 (Paris: Aubier, 1992), pp. iii-xxxv. 
the unconscious in a way that both acknowledges and maintains the étrangèreté of that unconscious.

Laplanche's challenge to psychoanalysis - based on his resurrection of the seduction theory - is one that opposes a self-generated or self-centred version of human subjectivity. ${ }^{5}$ What the seduction theory makes evident for Laplanche is the radical other-centeredness of the human being, an otherness generated by an alien unconscious. This otherness may indeed be an avatar of terror, but it is a terror that lies at the decentred heart of the human, and only by accepting the otherness that the unconscious introduces can humans have the potential to appreciate not only the terrors of the unconscious, but also its pleasures.

\section{Nineteen Eighty-four and the Promise of Transcendence}

The regime headed by Big Brother, which rules over the state of Oceania in Nineteen Eighty-four, is both narcissistic and terroristic. Its brand of terror is narcissistic insofar as the people of Oceania are encouraged to reduce all their experiences to a conception of collective selfhood. As Martha Nussbaum has recently noted, in Nineteen Eighty-four 'the people of Oceania identify strongly with the state and see its triumphs as their own'. ${ }^{6}$ Their self-identity and selfexpression are fused with the hopes and aims of the state. 'Lacking a clear sense of the boundaries between self and other', Nussbaum writes, 'lacking, indeed, any robust sense of other, they gain narcissistic triumph through absorption in the state. ${ }^{7}$ In Nineteen Eighty-four any sense of otherness is experienced only in terms of the self, as a form of collective self-expression: 'The collectivity is a vehicle of narcissistic triumph."

This narcissistic absorption signifies a first form of terror, a terror which is organized by the quest for transcendence. That transcendence is one in which the boundaries between self and other are dissolved. In such a state of transcendence, the self and its others need no longer be opposed to one another, or even distinguished; rather, all determinations of otherness are reduced to the sphere of the self. Therefore, in Oceania, all forms of otherness are either subsumed by the self - others become like me - or are completely denied any relation to the self - others are enemies. It is in this way that the first form of terror carries with it the promise of transcendence: the other will either become part of me (and hence

5. This distinction between self-centred (what Laplanche calls 'Ptolemaic') and other-centred ('Copernican') conceptions of psychoanalysis is central for Laplanche's writings. See, for example, the essays collected in La Révolution copernicienne inachevée.

6. Martha C. Nussbaum, 'The Death of Pity: Orwell and American Political Life', in On Nineteen Eighty-Four: Orwell and Our Future, ed. by Abbott Gleason, Jack Goldsmith and Martha C. Nussbaum (Princeton and Oxford: Princeton University Press, 2004), pp. 279-99 (p. 288).

7. Nussbaum, p. 288.

8. Ibid. 
its otherness will be transcended), or the other will exist only under the threat of its eradication (and will hence carry with it the promise of transcendence).

It will come as no surprise that a totalitarian regime, such as that which is portrayed in Nineteen Eighty-four, is predicated on a promise of transcendence. But here I want to stress two issues. The first point to be noted is that the attempt to transcend all otherness is reflected in certain approaches to psychoanalysis which try to tame or even eradicate the alien otherness that constitutes the unconscious. That is to say, some forms of psychoanalysis, ${ }^{9}$ beginning with certain tendencies in Freud himself, see the unconscious as little more than an impediment - a pathology - the transcendence of which provides the basis for a psychoanalytic cure. ${ }^{10}$ This tendency is perhaps nowhere more evident than in the notion of repressed memory, where the unconscious is posited as the outcome of a process of remembering which in one way or another 'goes wrong'. The unconscious itself is therefore understood as being automatically wrong, as pathological, and thus it only exists, from this perspective, as something to be overcome. Once the erroneous memories that have fallen into the unconscious are corrected and brought into contact with conscious thought, then a cure will have been performed. The cure is thus conceived as an eradication of that which is unconscious; the cure is based on an extinguishing of the unconscious. ${ }^{11}$

Therefore, in Nineteen Eighty-four, what transpires as a collective transcendence of otherness by way of a narcissistic fusion with the state can be mirrored in individual cases by a promise of transcending that otherness which forms the unconscious. This mirroring of collective transcendence by the promise of individual transcendence brings me to the second point I want to stress. I want to argue that Winston Smith, the hero of Nineteen Eighty-four, betrays a tendency towards a transcendence of the unconscious. In this way, his actions and aspirations end up being no different from those of the other citizens of Oceania. Winston is typically understood as someone who is deeply opposed to Big Brother and the totalitarian regime of Nineteen Eighty-four, indeed, this is how he understands his own actions: his actions are opposed to the Party. However, as Claude Lefort has deftly argued, Winston in fact exhibits all of the characteristics which ensure that ultimately he will accede to the regime. ${ }^{12}$ In the final account,

9. Laplanche's main targets are the proponents of ego psychology (e.g. Heinz Hartmann), but he is also critical of some of the trends that emerge from the British school of psychoanalysis (Melanie Klein, Donald Winnicott).

10. Laplanche is extremely critical of Freud in this respect. He criticizes Freud's belief that 'everything conscious was previously unconscious' insofar as it implies a notion of the unconscious which can be assimilated to conscious thought (see Laplanche, 'La Révolution copernicienne', pp. xi-xii). Similarly, he questions Freud's Wo es war, soll Ich werden for its reduction of the notion of a cure to strengthening the capacities of the ego and for thus reinforcing the self-centredness of the human subject (ibid., p. xxxv).

11. See Laplanche's comments in 'La Révolution copernicienne', p. xxi.

12. Claude Lefort, 'Orwell, le corps interposé', Passe-Present, 3 (1984), 80-97. 
Winston's conception of his existence is one that is not at odds with terror, and as such it cannot function as an effective opposition to Big Brother. Instead, his mythic belief in a potential fusion with the other - with O'Brien (a member of the inner party in whom Winston mistakenly puts his trust), with the 'Brotherhood' (the mythical underground resistance movement against Big Brother), with Julia (the woman with whom Winston falls in love) - singles him out from virtually the very beginning of the novel as someone who will quite naturally become complicit with the regime. ${ }^{13}$ As Lefort claims of Winston, 'qu'il y a quelque chose en lui qui se prête au fantasme qui gouverne totalitarisme'. ${ }^{14}$ Nussbaum also argues that, although 'Winston Smith is not a narcissist', he is nonetheless 'all too prone to narcissistic retreat and collapse'. ${ }^{15}$

In the end, then, Winston does succumb to narcissism, to the fusion of self and other that forms the bedrock of Nineteen Eighty-four's conception of terror. Aside from the fusion of self and other by way of instances of geste and regard that Lefort emphasizes, ${ }^{16}$ a key determinant in Winston's susceptibility to narcissistic self-centring emerges from his obsession with the past. ${ }^{17}$ This obsession with trying to know and master the past is nothing less than an attempt to know and master the unconscious, insofar as that unconscious is perceived as an element of memory that has gone wrong. ${ }^{18}$ Winston's many attempts to retrieve the past both at a personal and a collective level (whether through his diary, in his dreams, or via his discussions with the 'proles') stand as evidence of his quest for a transcendence of the unconscious, of his desire to eradicate the unconscious by bringing it into line with conscious thought. Winston is revealed to be a narcissist after all, and thus falls prey to a conception of terror based on a promise of transcendence.

13. Lefort points out that Winston is struck by a 'connection' with O'Brien very early in the novel. On only page 19, Orwell presents the reader with an intimation of Winston's totalitarian leanings: 'there was a fraction of a second when their eyes met, and for as long as it took to happen Winston knew - yes, he knew! - that O'Brien was thinking the same thing as himself' (Orwell, p. 19; cf. Lefort, p. 91).

14. Lefort, p. 90.

15. Nussbaum, p. 289.

16. Lefort argues that Winston is captured 'par un regard, par un geste du bras' - the 'glances' and 'gestures' are those of Julia and O'Brien, while an additional gesture - of his mother embracing his sister - haunts him as the remembrance of a lost past. See Lefort, p. 91.

17. Lefort claims of Winston that 'il est habité par le question du passé, il veut savoir' (p. 85), and that ultimately, for him, 'l'attrait du passé refont ainsi sourdement la croyance en l'immortalité' (p. 92).

18. It is Jean-François Lyotard, in a short commentary on Lefort's article, who stresses this point: Winston's life is one that is 'infiltré de rêveries, de rêves, de fantasmes, c'est-à-dire des formations les plus singulières de l'inconscient' ('Glose sur la résistance', in Le Postmoderne expliqué aux enfants: Correspondence 1982-1985 (Paris: Galilée, 1986), p. 138. 
It is in this way that Nineteen Eighty-four draws a very complex picture of terror. At the level of the individual - of Winston - terror is conceived, on the one hand, as a promise of transcending the other by uniting it with the self, and on the other hand, as an attempt to transcend the unconscious by restoring to the self what has been hidden from it. ${ }^{19}$ At the level of the collective, Orwell's conception of terror is more predictable - it is the terror of a totalitarian regime. But Nineteen Eighty-four's great achievement remains the way that Orwell links the totalitarian conception of terror at the level of the state with the psyche of the individual who conceives of himself in opposition to that state. It is Winston's inability to conceive of an otherness that is truly other which in the end makes him no different from anyone else in the Party.

\section{The Remains of the Day and the Terror of Submission}

Nineteen Eighty-four is a novel that by its very nature inspires reflection on terror and on the kinds of terror inherent in totalitarian regimes. By contrast, for Kazuo Ishiguro's understated, even quaint, romantic novel the question of terror could hardly seem relevant. There is certainly nothing on the surface of The Remains of the Day that would appear to give rise to terrors of any kind. But if my concern here is to uncover modes of terror, then the mode of existence that is characterized by the novel's main protagonist, a butler named Stevens, is, I want to argue, one of terror. Perhaps my main point here is to emphasize that terror need not involve overtly repressive regimes, spectacular catastrophes or gross exhibitions of evil. Rather, I want to try to point out that terror can operate quietly, even silently, and even that its mode of operation can be deeply satisfying, albeit in an alarmingly negative way.

In The Remains of the Day, Stevens is wholly devoted to his master. The concerns of the household and the duties it is his task to perform outweigh any other interests he may have. Much of the novel deals with Stevens's relationship with another member of the household staff, Miss Kenyon. He is deeply in love with her, and his love is reciprocated, but he nevertheless does everything in his power to conceal this love from himself, for to acknowledge it would amount to a negligence of his duties. In other words, he places his devotion to the household above his personal, subjective concerns: running the household is more important to him than falling in love. On this basis, the theme of the novel might be interpreted as that of 'lost love': if only Stevens had not been so attached to his duties and so devoted to his master, then he would have found true love and lived happily ever after. Because he was unable to forgo his duties, his one chance at true love and happiness was lost.

19. It is again worth drawing attention to Laplanche's criticisms of the notion of false memory or misremembering as that which forms the unconscious, for it is this conception of misremembering that guides Winston's attempts to transcend his unconscious. See Laplanche's criticisms in 'La Révolution copernicienne', p. xxi. 
Renata Salecl, however, provides a rather different interpretation of the novel. ${ }^{20}$ She argues that Stevens's devotion to his duties is not a barrier to his discovery of love, but instead that it is only because of his devoted duty that his love arises in the first place. According to the logic of this argument, if Stevens declared his love for Miss Kenyon over and above his duties, then the love itself would vanish; it is only by meticulously continuing his duties to his master that his love survives. Salecl thus claims that it is 'useless to search in Stevens for some hidden love that could not come out because of the ritual he rigidly engages in - all his love is in the rituals'. ${ }^{21}$

In accordance with the psychoanalytic precepts of her interpretation, Salecl argues that Stevens is guided in his behaviour by his ego ideal. The rituals and duties performed by him for his master are ones that take the place of his ego ideal. And Freud's words would seem to confirm that the kind of idealization in which Stevens is engaged is indeed a form of being-in-love. ${ }^{22}$ His ego ideal is constituted by his duties, which is to say that his duties are the objects, in accordance with the Freudian formula, that have been 'put in the place of the ego ideal'. ${ }^{23}$ Stevens's performance of his household tasks over and above his personal interests is a sure sign that the urgings of the ego ideal have replaced those of his ego. His ego might thus be said, as Freud argues, to be impoverished and usurped by the interests of the ego ideal: $;{ }^{24}$ all of Stevens's desires have been surrendered by his own ego and delivered up to the ideal of being a dutiful butler.

There is, however, a further determinant here. One might think that Stevens's sacrifice to the ego ideal, his humble renunciation of the interests of his own ego, would amount to a renunciation of all self-interest. It might thus be fair to argue that Stevens is the very opposite of a narcissist, that he is devoted to pleasing the other over and above the interests of himself. On the contrary, however, in cases like that of Stevens, the satisfactions derived from the ego ideal are deeply narcissistic, for, once again with reference to Freud's arguments in the Group Psychology, it is no less than the ego itself that is put in the place of the ego ideal. The ego thus obtains a sense of deep satisfaction from its impoverishment. In other words, Stevens's idealized performance of his duties bolsters his ego in a way that is satisfyingly narcissistic. Therefore, one would be entirely mistaken to argue that Stevens renounces his personal interests, that he is unhappy or that he is a shell of a man who merely performs tasks at the behest of his master. Rather, Stevens

20. Renata Salecl, (Per)versions of Love and Hate (London: Verso, 1998), pp. 6-33.

21. Ibid., p. 11.

22. See Freud's discussion of being-in-love in chapter VII of Group Psychology and the Analysis of the Ego (1921), Penguin Freud Library, 12 (Harmondsworth: Penguin, 1991), pp. 91-178.

23. Such is Freud's conclusion to above chapter in Group Psychology, p. 147.

24. Ibid., p. 144. 
clearly derives a sense of supreme fulfilment and enjoyment from his devotion to the ideal, for that devotion is one that is also in accord with the narcissistic strivings of his own ego.

If this is a mode of terror, and that is what I wish to argue here, then it exhibits many of the characteristics that were found in Nineteen Eighty-four. Primarily, the mode of terror in which Stevens is caught is one in which the self is identified with the other. Unlike Nineteen Eighty-four, however, where the unification of self and other was predicated on a promise of transcendence, in The Remains of the Day that unity is a product of submission: submission to the commands of the ego ideal.

What I am therefore arguing is that Stevens lives a life of terror. Broadly speaking, there are three factors that define this conception of submissive terror. The first factor is one of personal renunciation and self-sacrifice. Because of this renunciation, all decisions must be deferred to an external authority - and that is the second determinant. The third constituent arises from the first two: that one enjoys self-renunciation, for this mode of terror is based on the assumption that one's most intimate and personal desires do, after all, coincide with those that are prescribed by the external authority. As a result, submission to an external authority is justified on the basis of its production of a deep personal satisfaction.

If these are the constituents of submissive terror, then the character of Stevens satisfies all its requirements. His duties as a butler entail a complete renunciation of his personal desires. ${ }^{25}$ From a psychoanalytic perspective, one could claim that Stevens has given up on following the urges of his id, for all his actions and decisions are determined by his super-ego, especially insofar as his super-ego has become conflated with the aspirations of his ego ideal. And inasmuch as the superego is the agency of the unconscious in which is inscribed the internalization of external prohibitions and commands, then the second condition above is reached: all of Stevens's decisions and desires are deferred to an external authority, an externality that has been internalized in the form of a stern and demanding superego. Salecl provides a Lacanian explanation for this by declaring that Stevens effectively 'installs himself in the place of the Other, from where he then acts in a way that prevents any risk of encountering his desire' ${ }^{26}$ Finally, then, by acting in accordance with the demands of his super-ego or ego ideal, Stevens in fact achieves a level of deep personal satisfaction: he is convinced that the ego wholeheartedly desires the conditions that are prescribed for it by the super-ego. Thus, performing his duties gives him a deep sense of narcissistic fulfilment and

25. See Salecl, p. 11. Cf. Barry Lewis, Kazuo Ishiguro (Manchester: Manchester University Press, 2000), p. 94.

26. Salecl, p. 9. 
triumph. ${ }^{27}$ What one may have considered as Stevens's renunciation of desire is instead conceived by him as its fulfilment.

For this mode of submissive terror, terror is once again a narcissistic fusion of self and other, though for submissive terror, the other takes on the bearings of Lacan's big 'Other'. Stevens's submission to the laws determined by the Other are again a form of terror in which the alien nature of the other is denied (whether these laws are those laid down by the master of the household, by Stevens's aspiration to live up to the model of the great butler that his father was, or as part of Stevens's membership of the Hayes Society - a society for elite butlers). Stevens can only approach the other in terms of his submission to it. By fully submitting to the other, he obtains narcissistic fusion with it, he 'installs himself in the place of the Other' (as Salecl claims). ${ }^{28}$ These characteristics designate a second form of terror: narcissistic submission to the other.

The main discovery Laplanche wrests from Freud is that of an unconscious which necessitates, for the human being, an internal étrangèreté that is maintained and held in place by an external étrangèreté. One's recognition of the unconscious other within the self (das Andere) can only be made on the basis that this other is acknowledged in its otherness. At the same time, the acknowledgment of internal otherness goes hand-in-hand with an acknowledgment of other people (or the 'other person': der Andere).$^{29}$ This acknowledgment of the other — of the unconscious and of other people - goes to the heart of Laplanche's understanding of the 'other-centredness' of human subjectivity, his conviction that, for the human being, it is the other and not the self which is primary. 'L'inconscient', he argues, 'n'est donc en rien un autre "moi-même" en moi, éventuellement plus authentique que moi [...]. Il est l'autre-chose (das Andere) en moi, résidu refoulé de l'autrepersonne (der Andere) ${ }^{30}$

With these statements in mind, could it not be argued that in The Remains of the Day Stevens is eminently other-centred insofar as he 'installs himself in the place of the Other'? While on the surface this may appear to be the case, on deeper inspection it becomes clear that the otherness to which Stevens submits is not one

27. Barry Lewis astutely accounts for this sense of fulfilment by stressing Stevens's wish to 'inhabit' his role as butler, 'to inhabit it', as Stevens himself' claims, 'to the utmost' (Ishiguro, p. 43). He writes that 'The word "inhabit" is telling: the great butler is at home in the part he plays. It $i s$ home to him, not a temporary lodging' (Lewis, p. 85).

28. Salecl, p. 9.

29. Laplanche finds a distinction in Freud's writings between the other in general - das Andere - and the other person - der Andere. The distinction is crucial for Laplanche insofar as he traces the otherness constitutive of the unconscious back to the child's interactions with (and 'seduction' by) the other person (see 'La Révolution copernicienne').

30. Laplanche, 'Court traité de l'inconscient', Nouvelle Revue de psychanalyse, 48 (Autumn 1993), 69-96 (p. 90). 
that he recognizes as truly other, but is an other which he can conceive of only on the basis of his being unified with it. For Stevens there is no acknowledgment of either the internal étrangèreté of his unconscious or the external étrangèreté of the other person. It is this refusal of the alien-ness of the other that, like Winston in Nineteen Eighty-four, is constitutive of terror. Both Orwell and Ishiguro discover the most sinister functioning of terror: that it is at its most effective when it is at its most silent. It is Winston's refusal to believe that he too might be capable of terror that ultimately ensures he, quite to the contrary, will be capable of being folded into the ranks of the Party and succumb to the lures of its terrors, while for Stevens, in Ishiguro's novel, his submission to an other which he believes to be utterly incapable of terror, of étrangèreté, is again a sure signal that he will eventually conduct his life under the most severe reign of a silent terror.

\section{Innocence: the Incorporation of Terror}

Lucile Hadzihalilovic's film, Innocence, presents a conception of terror that differs markedly from those of Nineteen Eighty-four and The Remains of the Day. The mode of terror in Innocence is one of an alien other implanted in the human subject from the outside. As such, Innocence portrays a mode of terror that acknowledges the fundamental other-centeredness of the human being: here, the other is incorporated, and it is incorporated as other.

First of all, the film itself: after going through nearly two hours of fantasystrangeness, of not really knowing quite where the story of the film is going or what kind of world is being depicted in the girls' school on which the film focuses, suddenly the older students are bundled onto a train - it is time for their transition from the completely closed world of the school (the parc) to the open world that exists beyond the school's gates. When the girls arrive at their destination another school, this time not a closed one, but instead one in which they are free to explore the world beyond the school - they immediately make their way to a sunny courtyard in which there is a fountain. The girls begin to play in the fountain, splashing about in an excited fashion, as if responsive to their new-found freedom. Then one of the main characters, Bianca (Bérangère Haubruge), notices a boy, the first and only time in the film that a male character is given a face. Between Bianca and the boy there then ensues an extraordinary back-and-forth montage sequence of point-of-view shots and reverse-shots. They smile at each other: they are happy; for the first time in the film there is a sense of happiness. Bianca has finally left the stifling restrictions of the young girls' parc and has discovered something that verges on maturity: Bianca feels all at once that she has grown up - and it is a good feeling.

For the girls, and for Bianca in particular, this is a moment at which maturity is reached - biologically, psychologically and sexually. They have arrived at the properly sexualized world that emerges with puberty, a sexualization that had been denied the girls at the parc. The girls enter a world of understanding, a world in 
which they now have the capacity to make choices and determine their actions to a degree that autonomous or self-determining human subjects can.

Innocence is thus a chronicle of a childhood coming-of-age in ways that are strikingly similar to Laplanche's theorization of the child's passage into the adult world. In general terms, Laplanche theorizes this transition as one that progresses from non-knowledge to knowledge; the human child arrives in the world illequipped with the skills and understanding needed in order to survive, and as a result, the child has to rely on others - other people - in order to make the journey towards knowledge. All of the knowledge the child gains, therefore, is only ever knowledge that is offered to the child by the other: the child's entry into the adult world can only be predicated on the teachings or commandments that are delivered from other people.

These adult messages can indeed be characterized as forms of terror: they are traumatic intrusions into the child's world. ${ }^{31}$ These intrusions are, according to Laplanche, the markers of seduction: the adult continually directs demands and requests towards the child, even when the child is incapable of understanding those demands and requests. These messages that the adult directs to the child are received by that child, who then subsequently tries to make sense of them. ${ }^{32}$ The reception of messages coming from the other - seduction, per se - can be interpreted as the child's initial subjection to terror, as traumatic intrusions from the other person by means of which the child then attempts to construct the meanings that can give a modicum of sense to its world. For the child, this is a form of terror: an intrusion of the external, alien other of which the child is incapable of making sense. The child cannot be expected to understand these terroristic intrusions: at an early age, the child simply does not possess the skills and knowledge to enable the other's messages to be adequately translated. Therefore, as a result, that which fails to be translated or which is untranslatable falls into the unconscious: those things which are untranslatable form "le noyau de l'inconscient', writes Laplanche, and 'sont à concevoir comme ce qui échappe aux premières tentatives de l'enfant pour se construire une monde interhumain'. ${ }^{33}$

The key factor in understanding what unfolds in Innocence thus can be said to arise from the fact that the girls, while at the parc, are constantly being made to do things - to perform tasks, to follow rules and regulations - without having the slightest idea of why they are being made to do such things. The restrictive

31. Laplanche claims that 'l'intervention de l'autre nécessairement traumatisante' is characterized by something akin to pain [douleur] ("Masochisme et théorie de la séduction généralisée', in La Révolution copernicienne inachevée, pp. $439-456$ (p. 452).

32. Laplanche argues that the category of the message, as he calls it, is one of his most significant contributions to psychoanalysis. See, for example, his Nouveaux Fondemonts de la psychanalyse (Paris: Presses Universitaires de France, 1987).

33. Laplanche, 'Court traité', p. 76. 
regime that characterizes the parc, whereby the girls are bombarded with commands and messages that originate from others (their teachers, the headmistress, the parc's rules and customs) is thus analogous to the general situation of the child as theorized by Laplanche: messages are directed towards them which they are unable to adequately comprehend. ${ }^{34}$

Even more troubling - terrifying, even - for the child, is that the child has no choice but to submit to the messages sent by the other if that child is to ever make sense of the interhuman world: 'Avec le message', Laplanche contends, 'l'idée qu'il y a du sens existant, préexistant, proposé au sujet, et dont il n'est pas maître, dont il ne peut se rendre maître qu'en s'y soumettant'. ${ }^{35}$ And so too for the girls in the parc - they have no choice but to submit to the commands given to them. Mademoiselle Éva (Marion Cotillard), the dance teacher at the parc, even remarks at one point that 'l'obéissance est le seul chemin qui mène au bonheur'. Those who fail to submit to the parc's messages are doomed to failure - Laura (Olga Peytavi-Müller), for example, drowns while attempting to escape from the parc, while Alice (Lea Bridarolli) successfully escapes, but the implication is that she is not yet ready for the outside world. Only by obeying, by following the commands delivered by their teachers and the other customs of the parc, by submitting to them, can the girls gain knowledge and ultimately independence.

At the end of the film, the character of Bianca is held up as the one who achieves a proper sense of independence - that is certainly how I interpret Innocence's magnificent closing images. Throughout the film, Bianca accepts the task of submitting to the teachers' discourses; she accepts and incorporates, as it were, the messages directed to her from other people. She ultimately masters these messages insofar as she acknowledges that they come from the other and that their alterity is maintained (she does not try to make them hers). Perhaps this capacity for incorporating the other's message is nowhere more evident than when a member of the audience at one of the dance performances the older girls engage in each evening throws a rose and a pair of gloves to Bianca. She receives the rose and gloves - she is the recipient of the message - and she tries to make sense of this message. Later that evening, when she has returned to her room in the parc, she puts one of the gloves on her hand and gently caresses her thigh. The connotation is clearly sexual (Bianca is attempting to understand what sexuality means in an adult world), but even more than this, her gesture expresses the attempt to make sense of the other's message. What her act indicates is her attempt to incorporate the other's message, to make it part of her self - she puts the glove on her hand - but as an alien part of herself that originates in the other person;

34. The main figure in this regard is the character of Iris (Zoé Auclair) who constantly asks questions in an effort to understand the parc's rules and regulations.

35. Laplanche, 'L'Interprétation entre déterminisme et hermeneutique: une nouvelle position de la question', in La Révolution copernicienne inachevée, pp. 285-415, p. 410. 
that is, she does not touch herself with her own hand, but with the glove that has been sent to her as a message from the other person. Bianca's self-caress with the other's glove can thus be seen as an incorporation of the other, an attempt to bring into herself the traumatic, alien message that originates in the other person: an acknowledgment of the relation of alterity that the other person has with the self.

In this way, Innocence's mode of terror is quite distinct from those of Nineteen Eighty-four and The Remains of the Day. While Nineteen Eighty-four's mode of terror is based on a promise of transcendence that is achieved by a fusion of self and other, and The Remains of the Day outlines a mode of terror in which the self attains unity with the other by fully submitting to the other, Innocence portrays a mode of terror in which terror is incorporated as other. Only by incorporating this terror - that is, by incorporating the traumatic messages directed by the other towards the self - can terror be utilized by the subject as an internal étrangèreté that originates in and is held in place by an external étrangèreté. Only by accepting and incorporating the terror of the étrangèreté of the other can one break free from the terrors of narcissistic self-centredness. The narcissistic modes of terror - those of transcendence in Orwell and submission in Ishiguro - are predicated on denials of terror: Winston's belief that he is against the party, an anti-terrorist, and Stevens's enjoyment of his own submission to his master, are indications that these protagonists situate themselves beyond terror, that terror is not something of which they are a part. Nevertheless, each of these characters is utterly mistaken; indeed, it is their denial that they are implicated in modes of terror that betrays their complicity with the overt operations of terror.

In Innocence, on the contrary, Bianca incorporates the terrors with which she comes into contact. She does not try to deny or eradicate terror. She does not try to transcend terror, but nor does she merely submit to it. Instead, she incorporates terror; she takes terror into herself and makes it into something of which she is a part. In the same way that Innocence displays a terror which is to be incorporated rather than eradicated, so too is the unconscious something to be incorporated. There is no way of transcending the unconscious, while submitting to it tout court is certainly no viable way of dealing with it either. Rather, one must accept and acknowledge the unconscious as an other entity which resides in all of us, as an essential part of that which makes us human. And so too with terror: terror is also an essential part of that which makes us human. 